\title{
Comparison of LC-MS Assay and HPLC Assay of Busulfan in Clinical Pharmacokinetics Studies
}

\author{
Hongxia Lin, Susan Goodin, Roger K. Strair, Robert S. DiPaola, and Murugesan K. Gounder
}

The Cancer Institute of New Jersey, Robert Wood Johnson Medical School, University of Medicine and Dentistry of New Jersey, 195 Little Albany Street, New Brunswick, NJ 08901, USA

Correspondence should be addressed to Murugesan K. Gounder, goundemk@umdnj.edu

Received 24 October 2011; Accepted 16 November 2011

Academic Editors: A. Bouklouze and P. Campíns-Falcó

Copyright ( $\odot 2012$ Hongxia Lin et al. This is an open access article distributed under the Creative Commons Attribution License, which permits unrestricted use, distribution, and reproduction in any medium, provided the original work is properly cited.

Busulfan is used in preparative regimens for bone marrow transplantation and timely busulfan plasma concentration reporting is critical for subsequent dose adjustment. We compared two sensitive methods for pharmacokinetics studies including LC-MS assay and HPLC precolumn derivatization assay. Chromatographic separation was performed on a Gemini $\mathrm{C}_{18}$ column. Liquidliquid extraction with ethyl acetate was used for plasma sample preparation. Busulfan and internal standard $\left(\left[{ }^{2} \mathrm{H}_{8}\right]\right.$-busulfan) were detected as ammonium adducts at m/z 264.2 and 272.2 for LC-MS assay. For HPLC assay, the extraction from plasma was derivatized with 2-naphathalenethiol using synthesized internal standard (1,6-(methanesulfonyloxy)octane). The Ex and Em wavelength was $255 \mathrm{~nm}$ and $370 \mathrm{~nm}$. The limit of detection was $15.6 \mathrm{ng} / \mathrm{mL}$ and $7.8 \mathrm{ng} / \mathrm{mL}$ for HPLC and LC-MS assay and good linearity ranging from $31.25-1000 \mathrm{ng} / \mathrm{mL}$ for HPLC and $15.6-1000 \mathrm{ng} / \mathrm{mL}$ for LC-MS assay. The intra and interday assay precision were less than $9.2 \%$ and $12.0 \%$ for LC-MS and HPLC assay. The pharmacokinetic parameters were estimated using noncompartmental pharmacokinetic model with WinNonlin. Busulfan AUClast showed an average difference of $0.7 \%$ between the two methods. The LC-MS method is accurate, reproducible, and requires less specimen, sample preparation and analysis time over the HPLC assay, making busulfan monitoring faster and easier in clinical practice.

\section{Introduction}

Busulfan (1,4-busulfantanediol dimethanesulfonate) has been commonly used for the treatment of chronic myelogenous leukemia and for bone marrow transplantation. Busulfan has a narrow therapeutic index, and acute toxicity may be related to absorption and disposition of the drug and metabolites. High systemic exposure of busulfan has been shown to contribute to transplantation-related toxicities, such as veno-occlusive disease, interstitial pneumonia, or neurotoxicity $[1,2]$. The toxic effects were strongly related to high drug exposure by the steady-state plasma concentrations and/or area under the curve of busulfan. Therefore, therapeutic drug monitoring (TDM) has been considered of benefit for individual optimization of busulfan therapy [3].

Different analytical methods have been developed for busulfan measurement in plasma and other biological fluids, including GC and GC-MS [4-7], HPLC with UV detection [8-10], and with fluorescence detection $[11,12]$ and LCMS $[13,14]$. In the present study, we compared two published methods: (1) a rapid and accurate LC-MS assay with SIM mode, (2) a sensitive HPLC-FL assay using 2naphthalenethiol derivatization for the busulfan quantitation. Both methods were partially validated in small volume of plasma and applied to pharmacokinetics evaluation of busulfan in a phase I trial of in patients with acute myelogenous leukemia.

\section{Materials and Methods}

2.1. Chemicals. Busulfan, 1,8-octanediol, 2-naphthalenethiol and methane sulfonyl chloride were purchased from Sigma-Aldrich Co., (St. Louis, MO). $\left[{ }^{2} \mathrm{H}_{8}\right]$-busulfan was purchased from $\mathrm{C} / \mathrm{D} / \mathrm{N}$ isotopes Inc., Canada (Pointe-Claire, Quebec). HPLC-grade solvents methanol and acetonitrile were purchased from Fisher Scientific (Pittsburgh, PA). The control plasma from healthy volunteers used for the preparation of calibration standards was purchased from New Brunswick affiliated hospital blood bank (New Brunswick, NJ, USA). 


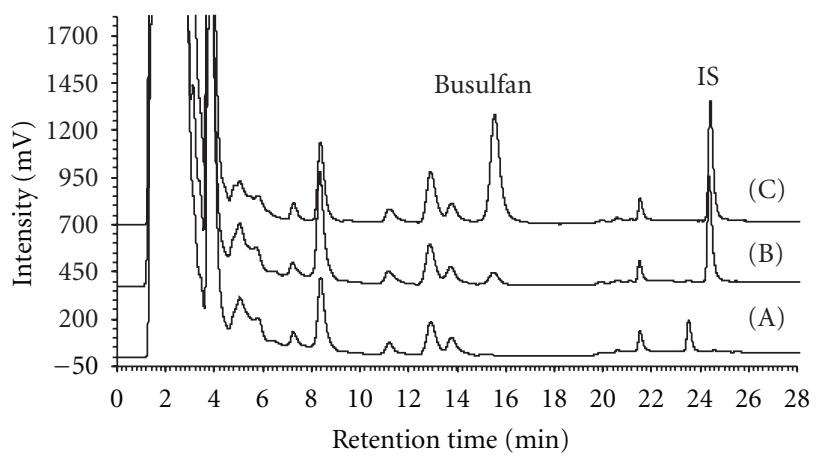

FIGURE 1: Representative HPLC chromatograms from extractions of blank plasma (A), $250 \mathrm{ng} / \mathrm{mL}$ busulfan and $200 \mathrm{ng} / \mathrm{mL}$ IS (B), and a patient plasma sample $(\mathrm{C})$.

2.2. Synthesis of Internal Standard for HPLC Assay. 1,8Bis(methanesulfonyloxy)octane was used as an internal standard and synthesized as per Chen's method [7]. Briefly, solution of methanesulfonyl chloride $(2.5 \mathrm{~g})$ in methylene chloride $(4.0 \mathrm{~mL})$ was added slowly to a solution of 1,8 octanediol $(1.46 \mathrm{~g})$, pyridine $(1.74 \mathrm{~g})$, and methylene chloride $(4.0 \mathrm{~mL})$ while stirring at $0^{\circ} \mathrm{C}$. The mixture was stirred at $25^{\circ} \mathrm{C}$ for $1 \mathrm{hr}$, extracted three times with water, and evaporated at reduced pressure.

2.3. Preparation of Standard Solutions. Stock solutions of busulfan $(1.0 \mathrm{mg} / \mathrm{mL})$, d8-busulfan $(5.0 \mathrm{mg} / \mathrm{mL}$, and synthesized internal standard $(5.0 \mathrm{mg} / \mathrm{mL})$ were prepared in acetonitrile. A set of busulfan calibration standards (15.6 $1000 \mathrm{ng} / \mathrm{mL}$ ) were prepared in control plasma by serial dilution of stock solutions. All the stock and the plasma standard solutions were stored at $-20^{\circ} \mathrm{C}$.

2.4. Busulfan HPLC-FL Assay. Plasma sample preparation followed Hara's method [11]. $300 \mu \mathrm{L}$ plasma standard or $100 \mu \mathrm{L}$ patient plasma samples diluted with $200 \mu \mathrm{L}$ water were spiked with $10 \mu \mathrm{L}$ internal standard $(20 \mu \mathrm{g} / \mathrm{mL})$. After extracted with $3 \mathrm{~mL}$ ethyl acetate, the organic phase was collected and evaporated to dryness at $45^{\circ} \mathrm{C}$. The residue was dissolved in $200 \mu \mathrm{L}$ ethanol, and $10 \mu \mathrm{L}$ each of $0.3 \mathrm{M}$ NAT solution (in acetone) and $1 \mathrm{M}$ sodium hydroxide. The tube was tightly closed and maintained at $85^{\circ} \mathrm{C}$ in a heating block for $1 \mathrm{hr}$. The sample solution was diluted to $500 \mu \mathrm{L}$ with methanol and N, N-dimethylformamide, and $25 \mu \mathrm{L}$ of the mixture was injected throughout the study. Quantitation of busulfan was performed using Hitachi 7000 series HPLC, equipped with a Hitachi L-7200 autosampler, L7100 quaternary pump, L-7480 fluorescence detector, and D7000 interface data processing software (Hitachi Co., Tokyo, Japan). The separations were performed on a Gemini $\mathrm{C}_{18}$ reversed-phase column $(100 \times 4.6 \mathrm{~mm}, 3 \mu \mathrm{m}$, Phenomenex Co., Torrance, CA). The fluorescence detector was set at Ex and Em wavelength of $255 \mathrm{~nm}$ and $370 \mathrm{~nm}$. LC conditions were as follows: mobile phase A: $0.1 \mathrm{M}$ ammonium acid solution $(\mathrm{pH}=7.0)$; mobile phase $\mathrm{B}: 100 \%$ acetonitrile; mobile phase C: $100 \%$ methanol; flow rate $1.0 \mathrm{~mL} / \mathrm{min}$; gradient, 0 to $15 \mathrm{~min}, 16 \% \mathrm{~A}, 4 \% \mathrm{~B}$ and $80 \% \mathrm{C} ; 15$ to $17 \mathrm{~min}$, $16 \%$ to $5 \% \mathrm{~A}, 4 \%$ to $5 \% \mathrm{~B}$ and $80 \%$ to $90 \% \mathrm{C} ; 17$ to $25 \mathrm{~min}$, $5 \% \mathrm{~A}, 5 \% \mathrm{~B}, 90 \% \mathrm{C} ; 25$ to $30 \mathrm{~min}, 16 \% \mathrm{~A}, 4 \% \mathrm{~B}$ and $80 \%$ C. The retention times of busulfan and the internal standard were $15.7 \mathrm{~min}$ and $25.2 \mathrm{~min}$, respectively.

Plasma busulfan concentrations were determined following the modification of Murdter's method [14]. $200 \mu \mathrm{L}$ plasma standard and $50 \mu \mathrm{L}$ patient plasma samples diluted with $150 \mu \mathrm{L}$ water and spiked with $5 \mu \mathrm{L}$ internal standard $\left(20 \mu \mathrm{g} / \mathrm{mL}\left[{ }^{2} \mathrm{H}_{8}\right]\right.$-busulfan) were added with $250 \mu \mathrm{L}$ water and extracted with $3 \mathrm{~mL}$ ethyl acetate. The organic phase was collected and evaporated to dryness at $45^{\circ} \mathrm{C}$. The residue was dissolved in $200 \mu \mathrm{L}$ mobile phase with $5 \mu \mathrm{L}$ acetic acid. The chromatographic separation was performed using the same Gemini $\mathrm{C}_{18}$ column at column temperature of $30^{\circ} \mathrm{C}$. The isocratic elution was used at $500 \mu \mathrm{L} / \mathrm{min}$ with mobile phase of $10 \mathrm{mmol} / \mathrm{L}$ ammonium acetate and $10 \mathrm{~mL} / \mathrm{L}$ acetic acid in water and acetonitrile $(30: 70)$. A Surveyor LC (Surveyor MS pump, Surveyor Autosampler) with TSQ Quantum mass spectrometer equipped with ESI source was used for analysis with Xcaliber data acquisition software (ThermoElectron, San Jose, CA). Electrospray setting parameters were as follows: ion spray voltage, $3800 \mathrm{v}$; capillary temperature $350^{\circ} \mathrm{C}$; sheath gas pressure 50 arbitrary units; Aux gas pressure 35 arbitrary units. Busulfan and $\left[{ }^{2} \mathrm{H}_{8}\right]$-busulfan were detected as ammonium adducts at $\mathrm{m} / \mathrm{z} 264.2$ and 272.2, respectively. The retention time of busulfan and $\left[{ }^{2} \mathrm{H}_{8}\right]-$ busulfan was $4.1 \mathrm{~min}$.

2.6. Assay Partial Validation. The partial validation was performed for both methods. The stability test and recovery of busulfan in plasma using ethyl acetate were not repeated since these studies were well established in references [11, 13]. Linearity was assessed by weighted linear regression (1/conc.) of the analyte-internal standard peak area ratios for the LC-MS assay and by linear regression for the HPLCFL assay. The intra- and interday precision and accuracy were measured by quality control plasma samples for both methods. The limit of detection (LOD) was defined as signal/noise ratio of 3 . The limit of quantitation (LOQ) was defined at the lowest drug concentration that can be determined with precision and accuracy of less than $20 \%$.

2.7. Pharmacokinetics Study. The pharmacokinetic study was performed in a phase I trial of busulfan in patients with acute myelogenous leukemia. Busulfan was administered at $80 \mathrm{mg} / \mathrm{m}^{2}$ i.v. infusion. Blood samples were collected at the end of the infusion and 15, 30, 60, 240, 300, $360 \mathrm{~min}$ after the end of infusion. The plasma was separated and kept at $-80^{\circ} \mathrm{C}$ until analysis.

The pharmacokinetic parameters for each individual were determined by noncompartmental analysis (WinNonlin, version 2.1; Pharsight Corp.). Estimates of clearance $(\mathrm{CL}), \mathrm{AUC}_{\text {last }}$, and half-life $\left(t_{1 / 2}\right)$ were generated. Results are expressed as mean and standard deviation. The agreement of patient plasma concentrations and $\mathrm{AUC}_{\text {last }}$ and obtained by the two methods was assessed by two-tailed $t$-test. 
TABLE 1: Precision and accuracy of the HPLC-FL and LC-MS assay (data is presented as mean \pm S.D.).

\begin{tabular}{|c|c|c|c|c|c|c|}
\hline \multirow{2}{*}{ Busulfan conc. (ng/mL) } & \multicolumn{3}{|c|}{ Intraday $(n=4)$} & \multicolumn{3}{|c|}{ Inter-day $(n=4)$} \\
\hline & Measured & RSD (\%) & Bias $(\%)$ & Measured & RSD (\%) & Bias $(\%)$ \\
\hline \multicolumn{7}{|l|}{ HPLC-FL } \\
\hline 31.25 & $32.6 \pm 3.9$ & 12.0 & 4.3 & $31.8 \pm 2.2$ & 7.0 & 1.8 \\
\hline 125.0 & $128.8 \pm 10.1$ & 7.9 & 3.1 & $128.1 \pm 6.3$ & 4.9 & 2.5 \\
\hline 1000.0 & $1000.5 \pm 32.0$ & 3.2 & 0.05 & $1014.2 \pm 18.2$ & 1.7 & 1.4 \\
\hline \multicolumn{7}{|l|}{ LC-MS } \\
\hline 15.6 & $15.6 \pm 1.4$ & 9.2 & 0.1 & $16.1 \pm 0.4$ & 2.6 & 3.0 \\
\hline 125.0 & $122.4 \pm 5.3$ & 4.4 & -2.1 & $124.6 \pm 3.3$ & 2.7 & -0.3 \\
\hline 1000.0 & $1011.0 \pm 13.6$ & 1.3 & 1.1 & $1010.6 \pm 9.6$ & 1.0 & 1.1 \\
\hline
\end{tabular}
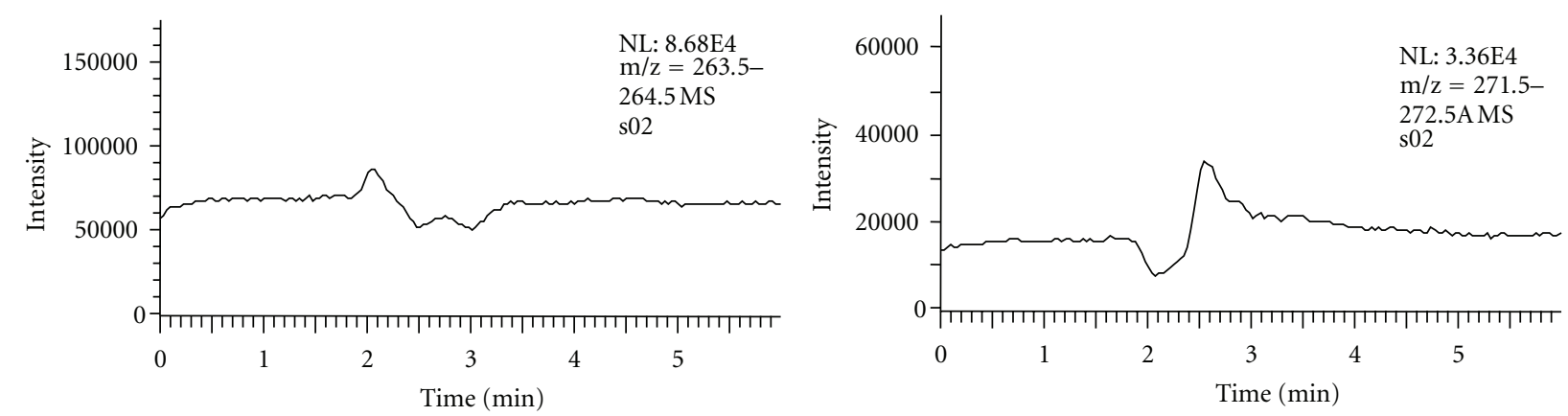

(a)
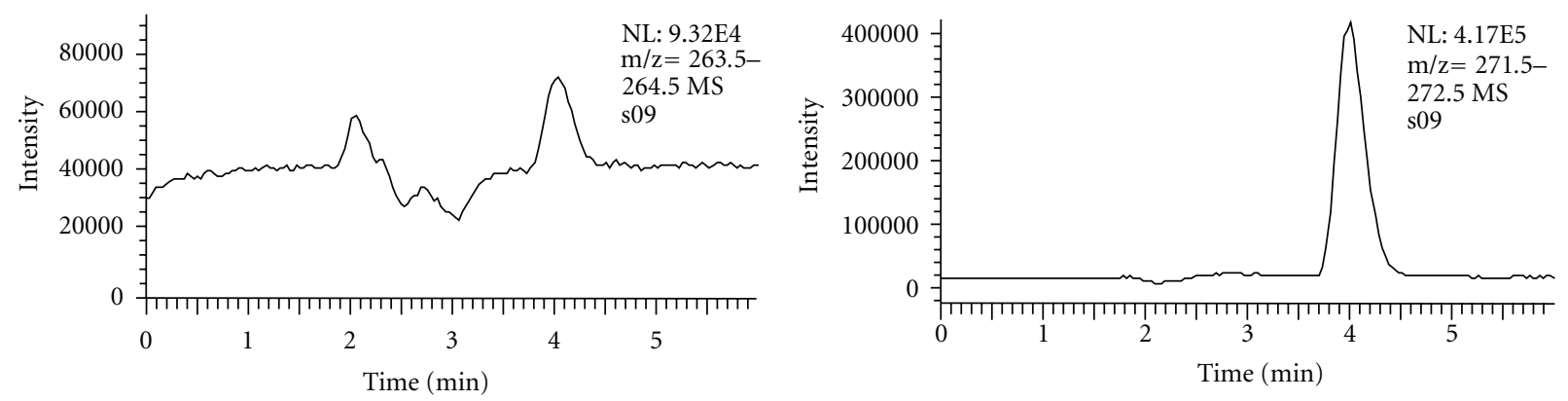

(b)
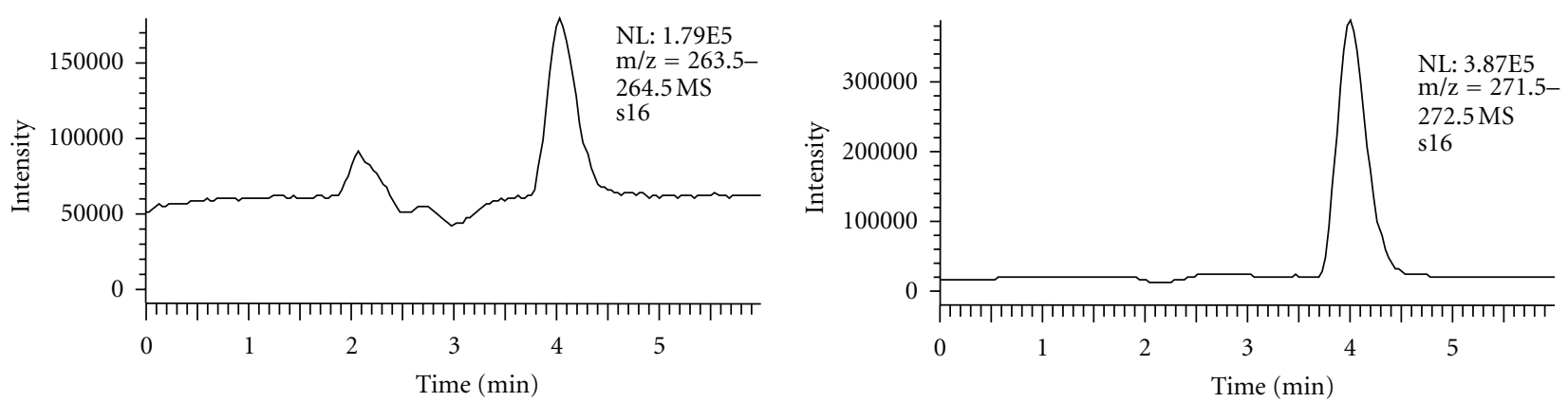

(c)

FIGURE 2: Representative LC-MS chromatograms from extractions of blank plasma (a), $250 \mathrm{ng} / \mathrm{mL}$ busulfan (m/z 264.2) and 200 ng/mL d8-busulfan (m/z 272.2) (b), and a patient plasma sample (c).

\section{Results and Discussion}

3.1. HPLC-FL Assay. Representative chromatograms of busulfan and internal standard in plasma are shown in Figure 1. Calibration curve for busulfan was in good linearity ranging from 31.25 to $1000 \mathrm{ng} / \mathrm{mL}\left(r^{2}, 0.9991 \pm 0.0007\right.$, mean \pm S.D., $n=4)$. The lowest LOD was $15.6 \mathrm{ng} / \mathrm{mL}$ and the lower limit of quantitation was $31.25 \mathrm{ng} / \mathrm{mL}$, observed with acceptable and reproducible precision and accuracy (Table 1). The above linearity range was suitable for busulfan 


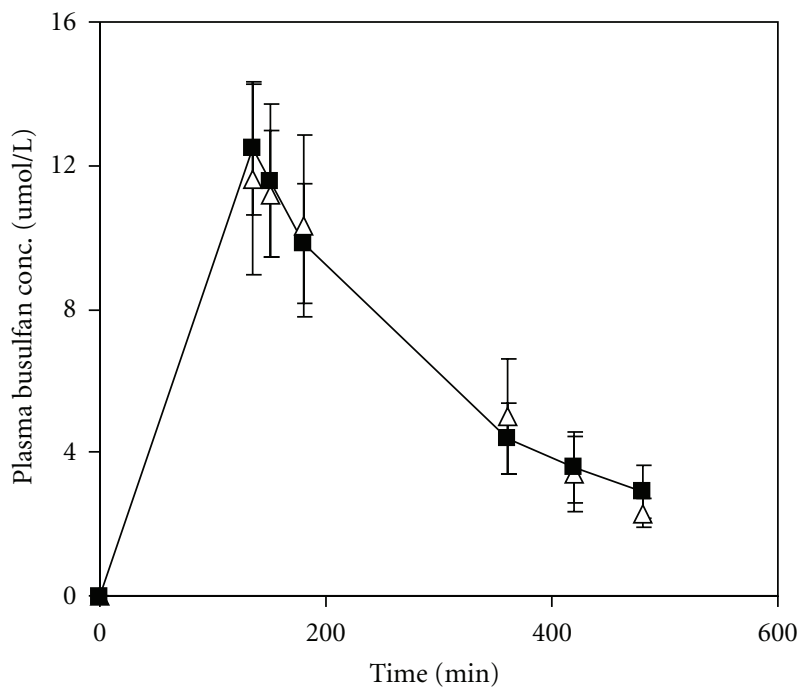

$\triangle \quad$ HPLC-FL

$\rightarrow$ LC-MS

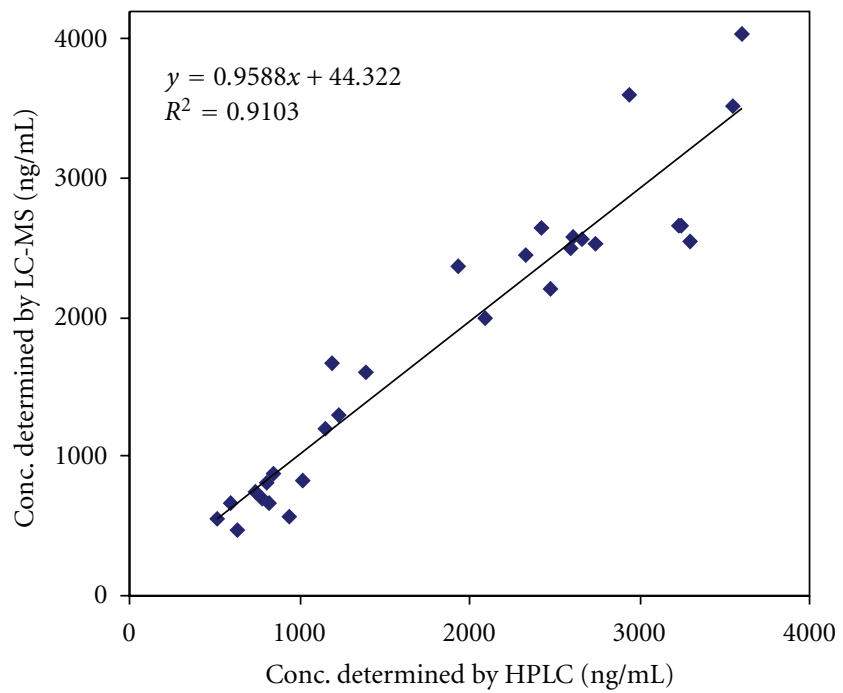

(b)

FIGURE 3: (a) Plasma concentration-time curves of patients obtained by HPLC and LC-MS (treatment of $80 \mathrm{mg} / \mathrm{m}^{2}$ busulfan i.v. infusion over 2 hr). (b) Correlation between the measurements between LC-MS and HPLC.

concentration detection in patient plasma in this study. The sensitivity is sufficient to meet the requirement for quantitation of busulfan. Table 1 summarizes precision and accuracy results at three quality control samples in plasma. The precision was less than $12.0 \%$ and the accuracy ranged from $0.05 \%$ to $4.3 \%$. Intra- and interday precision and accuracy were satisfactory for bioanalytical method validation.

3.2. LC-MS Assay. Chromatograms resulting form the extractions of a blank plasma sample, a quality-control sample $(125 \mathrm{ng} / \mathrm{mL})$, and a patient plasma sample are shown in Figure 2. Because of the highly selective detection method, there were no interfering peaks in blank plasma sample. This assay requires only $200 \mu \mathrm{L}$ plasma for accurate measurement at lower concentration $(15.6 \mathrm{ng} / \mathrm{mL})$. The small patient plasma volume $(50 \mu \mathrm{L})$ is more appropriate when TDM for busulfan was performed in children. Calibration curves were linear over the concentration range from 15.6 to $1000 \mathrm{ng} / \mathrm{mL}$, with correlation coefficient of $0.9994 \pm 0.0004(n=4)$. The limit of detection and limit of quantification were $7.8 \mathrm{ng} / \mathrm{mL}$ and $15.6 \mathrm{ng} / \mathrm{mL}$, respectively. The accuracy and precision values are shown in Table 1 . The intra- and interassay precision was less than $9.2 \%$ and the accuracy ranged from -2.1 to $3.0 \%$.

3.3. Pharmacokinetics Application of HPLC and LC-MS Assay. We compared busulfan plasma concentrations determined by HPLC and LC/MS assay in samples from five patients receiving $80 \mathrm{mg} / \mathrm{m}^{2}$ busulfan in a phase I clinical trial (Figure 3(a)). The good linear correlation $\left(R^{2}=0.91\right.$, with slope of 0.95) was obtained between concentration in two different assays (Figure 3(b)). Also the AUC showed 0.9\% difference between the two assays (Table 2). Paired $t$-test
TABLE 2: Estimated AUClast by the HPLC and LC-MS assay.

\begin{tabular}{lccc}
\hline \multirow{2}{*}{ Patient ID } & \multicolumn{3}{c}{$\mathrm{AUC}_{0-6 \mathrm{hr}}(\mu \mathrm{mol} / \mathrm{L} * \min )$} \\
& HPLC & LC-MS & Difference \\
\hline$\# 1$ & 2404.6 & 2498.6 & $3.8 \%$ \\
$\# 2$ & 3054.5 & 3151.7 & $3.1 \%$ \\
$\# 3$ & 2878.3 & 3209.1 & $10.3 \%$ \\
$\# 4$ & 2573.7 & 2403.1 & $-7.1 \%$ \\
$\# 5$ & 3928.0 & 3434.9 & $-14.4 \%$ \\
Average & 2967.8 & 2939.5 & $-0.9 \%$ \\
\hline
\end{tabular}

showed no significant difference between concentrations measured by two assays. These analyses indicate that the two methods yield very similar results for pharmacokinetic evaluation.

\section{Conclusion}

Two methods including HPLC and LC-MS were compared for plasma busulfan quantitation. Both assays are precise, sensitive, and accurate to meet the quantitation of busulfan in plasma. The LC/MS assay avoids time-consuming sample derivatization step and allows for low volume sample analysis. The LC/MS assay is well suited for the rapid and accurate measurement of busulfan in clinical drug monitoring.

\section{Acknowledgment}

The authors gratefully acknowledge the financial support provided by the Cancer Institute of New Jersey (New Brunswick, NJ, USA). 


\section{References}

[1] G. Vassal, A. Deroussent, O. Hartmann et al., "Dose-dependent neurotoxicity of high-dose busulfan in children: a clinical and pharmacological study," Cancer Research, vol. 50, no. 19, pp. 6203-6207, 1990.

[2] S. I. Bearman, "The syndrome of hepatic veno-occlusive disease after marrow transplantation," Blood, vol. 85, no. 11, pp. 3005-3020, 1995.

[3] N. Krivoy, E. Hoffer, Y. Lurie, Y. Bentur, and J. M. Rowe, "Busulfan use in hematopoietic stem cell transplantation: pharmacology, dose adjustment, safety and efficacy in adults and children," Current Drug Safety, vol. 3, no. 1, pp. 60-66, 2008.

[4] R. B. Burns, J. R. Heggie, and L. Embree, "A gaschromatographic assay method for busulfan with sensitivity for test dose therapeutic monitoring," Journal of Pharmaceutical and Biomedical Analysis, vol. 13, no. 9, pp. 1073-1078, 1995.

[5] W. K. Lai, C. P. Pang, L. K. Law, R. Wong, C. K. Li, and P. M. P. Yuen, "Routine analysis of plasma busulfan by gas chromatography-mass fragmentography," Clinical Chemistry, vol. 44, no. 12, pp. 2506-2510, 1998.

[6] M. Abdel-Rehim, Z. Hassan, L. Blomberg, and M. Hassan, "On-line derivatization utilizing solid-phase microextraction (SPME) for determination of busulphan in plasma using gas chromatography-mass spectrometry (GC-MS)," Therapeutic Drug Monitoring, vol. 25, no. 3, pp. 400-406, 2003.

[7] T. L. Chen, L. B. Grochow, L. A. Hurowitz, and R. B. Brundrett, "Determination of busulfan in human plasma by gas chromatography with electron-capture detection," Journal of Chromatography, vol. 425, no. 2, pp. 303-309, 1988.

[8] J. R. Heggie, M. Wu, R. B. Burns et al., "Validation of a high-performance liquid chromatographic assay method for pharmacokinetic evaluation of busulfan," Journal of Chromatography B, vol. 692, no. 2, pp. 437-444, 1997.

[9] M.-H. Quernin, B. Poonkuzhali, Y. Médard et al., "Highperformance liquid chromatographic method for quantification of busulfan in plasma after derivatization by tetrafluorothiophenol," Journal of Chromatography B, vol. 721, no. 1, pp. 147-152, 1999.

[10] D. S. L. Chow, H. P. Bhagwatwar, S. Phadungpojna, and B. S. Andersson, "Stability-indicating high-performance liquid chromatographic assay of busulfan in aqueous and plasma samples," Journal of Chromatography B, vol. 704, no. 1-2, pp. 277-288, 1997.

[11] S. Hara, M. Tsuchie, R. Tsujioka et al., "High-performance liquid chromatographic quantification of busulfan in human serum after fluorescence derivatization by 2naphthalenethiol," Analytical Sciences, vol. 16, no. 3, pp. 287-291, 2000.

[12] J. E. Peris, J. A. Latorre, V. Castel, A. Verdeguer, S. Esteve, and F. Torres-Molina, "Determination of busulfan in human plasma using high-performance liquid chromatography with precolumn derivatization and fluorescence detection," Journal of Chromatography B, vol. 730, no. 1, pp. 33-40, 1999.

[13] E. Oliveira Dos Reis, R. Vianna-Jorge, G. Suarez-Kurtz, E. Luiz Da Silva Lima, and D. De Almeida Azevedo, "Development of a rapid and specific assay for detection of busulfan in human plasma by high-performance liquid chromatography/electrospray ionization tandem mass spectrometry," Rapid Communications in Mass Spectrometry, vol. 19, no. 12, pp. 1666-1674, 2005.
[14] T. E. Mürdter, J. Coller, A. Claviez et al., "Sensitive and rapid quantification of busulfan in small plasma volumes by liquid chromatography-electrospray mass spectrometry," Clinical Chemistry, vol. 47, no. 8, pp. 1437-1442, 2001. 


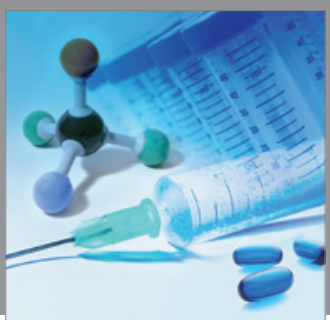

International Journal of

Medicinal Chemistry

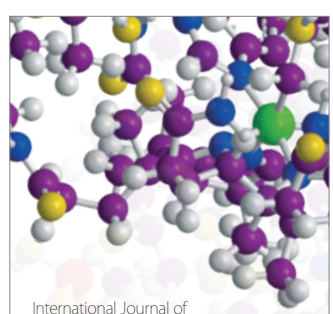

Carbohydrate Chemistry

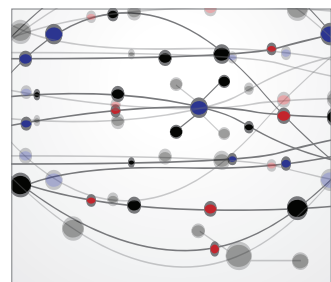

The Scientific World Journal
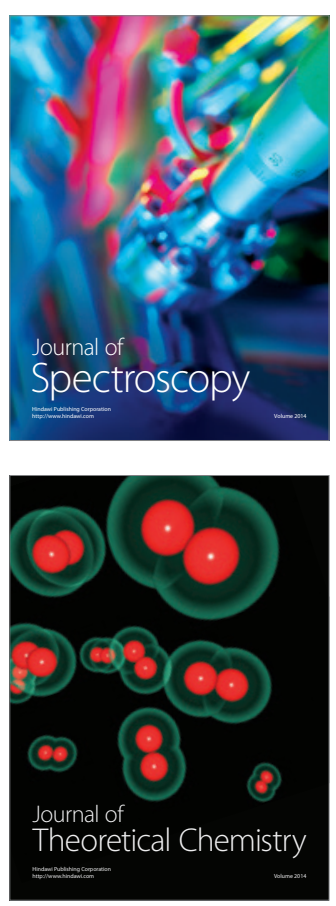
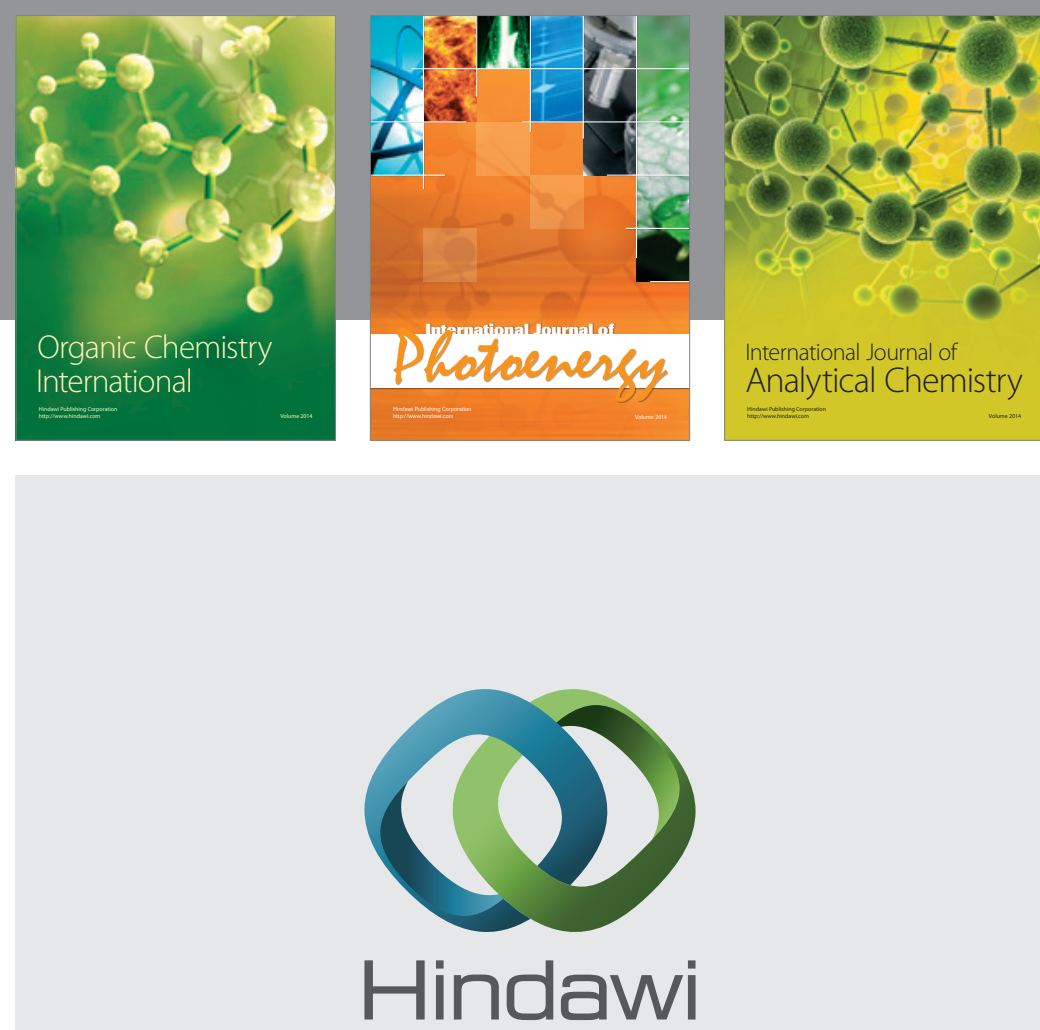

Submit your manuscripts at

http://www.hindawi.com
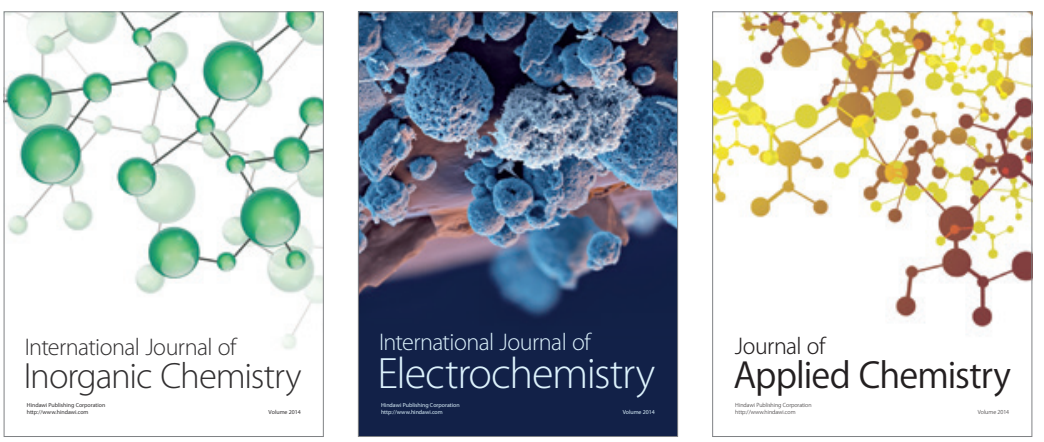

Journal of

Applied Chemistry
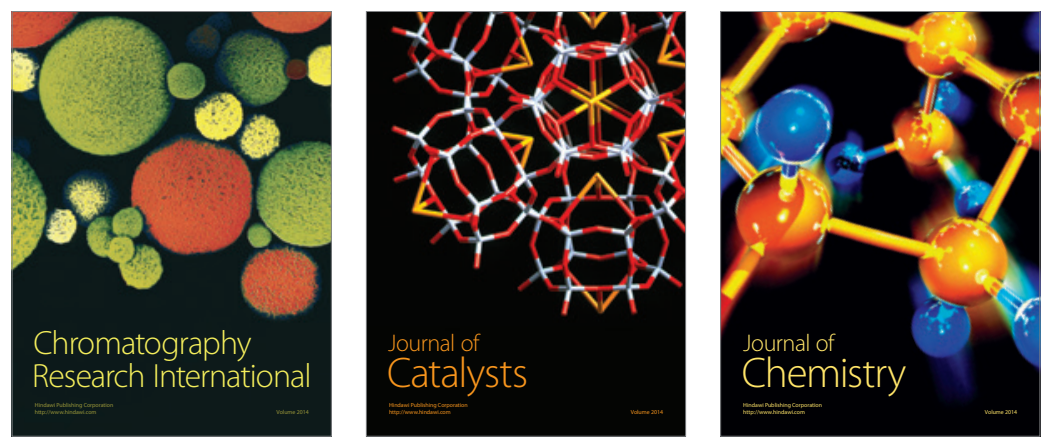
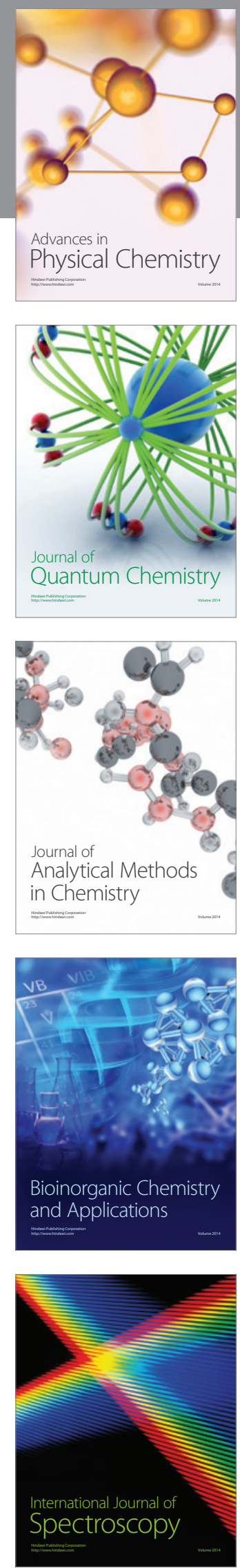